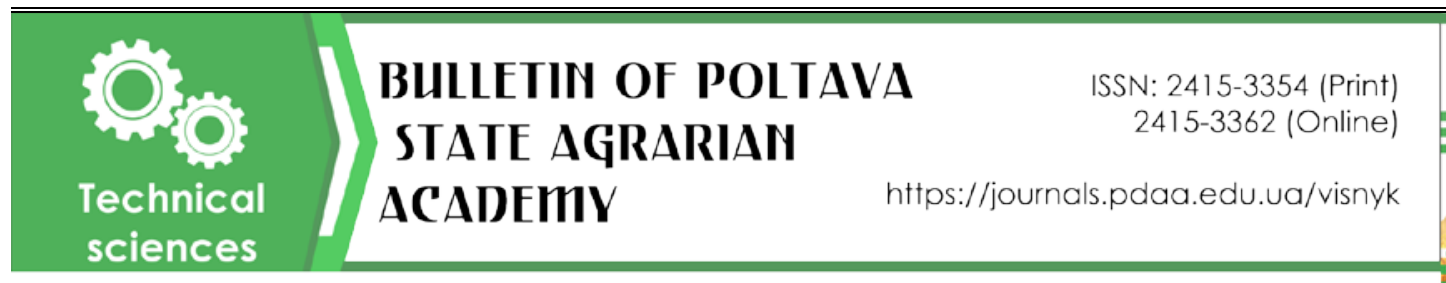

riview article | 621.9.48 | doi: 10.31210/visnyk2020.04.36

\section{STUDYING RENOVATION METHODS OF WORN DETAILS OF AGRICULTURAL MACHINERY}

\author{
O. V. Ivankova ${ }^{1 *}$ \\ O. V. Garashchuk ${ }^{2}$ \\ V. I. Kutsenko ${ }^{3}$ \\ V. V. Shcherbyna ${ }^{1}$ \\ D. V. Chyzhevs'kyy ${ }^{1}$ \\ Ya. V. Babych ${ }^{1}$ \\ M. O. Tykhonov ${ }^{1}$
}

\author{
ORCID (iD) 0000-0003-1825-0262 \\ ORCID (iD) 0000-0001-5572-5357 \\ ORCID (iD 0000-0003-3102-0744
}

\footnotetext{
${ }^{1}$ Poltava State Agrarian Academy, 1/3, Skovorody str., Poltava, 36003, Ukraine

${ }^{2}$ State Service of Education Quality of Ukraine, 18, Isaakiana str., Kyiv, 01135, Ukraine

${ }^{3}$ Public Institution "Institute of Environmental Economics and Sustainable Development of the National

Academy of Sciences of Ukraine”, 60, Shevchenko Av., Kyiv, 01032, Ukraine

*Corresponding author

E-mail: olena.ivankova@pdaa.edu.ua
}
How to Cite Chyzhevs'kyy, D. V., Babych, Ya. V., \& Tykhonov, M. O. (2020). Studying renovation methods of worn details of agricultural machinery. Bulletin of Poltava State Agrarian Academy, (4), 283-292. doi: 10.31210/visnyk2020.04.36

An important direction of technical service industry is the development of rational technologies for the restoration of worn parts of agricultural machinery. The modern branch of technical service requires the development of new technologies for strengthening the surfaces of machine parts to improve their performance. The purpose of the work is to identify the optimal method for renovating worn parts of agricultural machinery, forming a wear-resistant surface structure, having a low process temperature and practically eliminating the formation of thermal impact zone. It must have high economic and environmental parameters of the technological process. During the research we analyzed data from literature sources, the experience of leading technical service enterprises, described and compared the characteristics of technological processes of details' renovation; generalized the results of analysis and comparison of characteristics and developed conclusions as to the optimal method of restoration of machine worn parts. Based on the results of analyzing literature sources and the experience of advanced technical service enterprises, the advantages and disadvantages of the method of electric spark alloy were revealed. The possibilities of using it to restore worn surfaces of agricultural machinery parts have been clarified. It has been found that the method of electrical spark alloying is optimal for the repair of details. It provides high strength of adhesion of the applied layer; does not have a thermal effect on the detail; provides an opportunity of applying local strengthening of separate detail parts without dismantling the machine unit. Electrical spark alloying is characterized by: low energy consumption, small and mobile technological equipment, the process is environmentally friendly. It outperforms most traditional methods of restoring parts. The trends in the development of electric spark alloying technologies involve the replacement of expensive refractory components of electrode materials with new, cheaper, but effective. This makes it promising and quite attractive for research and application in production to strengthen and restore worn machine parts. Taking 


\title{
TEХНІЧНI НАУКИ
}

into account the simplicity of the equipment used for electric spark finishing, this method of renovation can be recommended for use in technical service workshops.

Key words: restoration (renovation), method, technology, strengthening, electrical spark alloying, reliability.

\section{ДОСЛІДЖЕННЯ МЕТОДІВ ВІДНОВЛЕННЯ ЗНОШЕНИХ ДЕТАЛЕЙ СІЛЬСЬКОГОСПОДАРСЬКОЇ ТЕХНІКИ}

\author{
О. В. Іванкова ${ }^{1}$, О. В. Гаращук ${ }^{2}$ В. І. Куценко ${ }^{3}$ В. В. Щербина ${ }^{1}$, Д. В. Чижевський, Я. В. Бабич \\ М. О. Тіхонов ${ }^{1}$ \\ ${ }^{1}$ Полтавська державна аграрна академія, м. Полтава, Україна \\ 2 Державна служба якості освіти України, м. Київ, Україна \\ ${ }^{3}$ Державна установа «Інститут економіки природокористування та сталого розвитку Національної \\ академії наук України», м. Київ, Україна
}

Актуальним напрямом у розвитку галузі технічного сервісу є розробка раціональних технологій відновлення зношених деталей сільськогосподарської техніки. Мета роботи - виявити оптимальний метод для відновлення зношених деталей сільськогосподарської техніки, який формує зносостійку поверхневу структуру, практично виключає утворення зони термічного впливу. До того ж має високі економічні та екологічні параметри технологічного прочесу. Для досягнення мети проведено аналіз даних літературних джерел, досвіду підприємств технічного сервісу, порівняння характеристик технологічних процесів; узагальнення результатів аналізу та порівняння методів, а також пропозииї щчодо оптимального методу відновлення зношених деталей машин. Грунтуючись на результатах проведених досліджень, виявили переваги та недоліки методу електроіскрового легування. 3'ясували можливості використання його для відновлення зношених поверхонь деталей машин. Виявлено, що метод електроіскрового легування є оптимальним для ремонту деталей. Він забезпечує високу міцність зчеплення нанесеного шару; не чинить термічного впливу на деталь; забезпечує можливість застосування місиевого зміџнення окремих ділянок деталі без розбирання агрегату, машини. Електроіскровому легуванню притаманні такі властивості: низька енерноємність, малогабаритне $i$ мобільне технологічне обладнання, процес є екологічно чистим. Цей метод є найдоцільнішим з усіх традииійних методів відновлення деталей. Тенденції розвитку технологій електроіскрового легування передбачають заміну дорогих тугоплавких компонентів електродних матеріалів більш дешевими, але ефективними. Це робить його перспективним і досить привабливим для досліджень та застосування у виробництві для зміџнення та відновлення зношених деталей машин. Зважаючи на простоту використовуваного для електроіскрової обробки обладнання, ией спосіб відновлення може бути рекомендований для застосування в майстернях технічного сервісу.

Ключові слова: відновлення, метод, технологія, змічнення, електроіскрове легування, надійність.

Актуальність проблеми обумовлена необхідністю виконання досліджень з метою розвязання проблем підвищення надійності сільськогосподарської техніки.

Експлуатація сільськогосподарської техніки потребує високого рівня надійності деталей та спряжень $[1,2]$. У процесі експлуатації машин, по мірі зношування деталей, їхні властивості погіршуються: має місце зниження фізико-механічних характеристик, твердості. Одночасно можуть виникати та розвиватися механічні пошкодження: мікротріщини, пори та інші [6, 9].

Економічні умови розвитку аграрного виробництва і технічного сервісу, нові стандарти суттєво підвищують вимоги до економічних та екологічних параметрів технологічних процесів поверхневого зміцнення деталей машин [3, 4]. Основні вимоги: забезпечення високої стійкості до спрацювання і довговічності відновлених поверхонь при незначних виробничих затратах на організацію технологічного процесу і використання недорогих матеріалів $[5,10]$.

Розглядаючи питання виготовлення, обробки та відновлення деталей машин, відзначимо, що поряд із застосуванням механічних методів (різання, обробка тиском), використовуються також сучасні наукомісткі методи електрофізичної обробки матеріалів. До таких методів відноситься електроіскрова, електроерозійна обробка деталей $[4,5]$. Електроіскрові технології використовують для розвязання 


\section{ТЕХНІЧНІ НАУКИ}

завдань щодо обробки різних деталей та інструментів, відновленню розмірів зношених деталей, нанесення покриттів зі спеціальними властивостями $[7,8]$.

Завдання підвищення надійності та довговічності сільськогосподарської техніки розвязуються шляхом покращення експлуатаційних властивостей поверхневих шарів відновлених деталей, створенням нового рельєфу поверхонь, а також нанесенням покриттів необхідної товщини.

Аналізуючи літературні дані про дослідження і застосування методів електроіскрової обробки, зокрема і електроіскрового легування, зазначимо, що до сьогодні відсутня оцінка доцільності застосування електроіскрових технологій при відновленні зношених деталей машин. Тобто існує необхідність порівняння переваг і недоліків електроіскрового легування з іншими методами відновлення зношених деталей машин [8, 9].

Отже, дослідження з пошуку нових, сучасних методів відновлення та зміцнення деталей для виявлення оптимального методу з відновлення зношених деталей сільськогосподарської техніки, на наш погляд, $\mathrm{e}$ найбільш актуальними і представляють практичний інтерес.

\section{Електролітичний метод відновлення зночених поверхонь}

Одне з провідних місць у зміцненні поверхонь при відновленні зношених деталей машин, підвищенні їх зносостійкості, займає електролітичний метод. При використанні електролітичних методів, нанесенні різних видів гальванічних покриттів створюються зносостійкі, корозійностійкі, антифрикційні поверхневі покриття деталей машин [13].

Для ремонту деталей сільськогосподарської техніки найчастіше застосовують: хромування, нікелювання, цинкування, кадмування.

Електролітичне хромування займає особливе місце $[10,14]$. Застосування хромування забезпечує: відновлення розмірів зношених деталей (причому, товщина покриття досягає до 0,3 мм); підвищення зносостійкості поверхні; забезпечує мікротвердість поверхні HV 1000-1100 МПа. Електролітичний хром не змінює властивостей при підвищеній температурі, стійкий проти корозії. Твердість гальванічних покриттів деталей машин хромонікелевими ( $\mathrm{Cr}-\mathrm{Ni}$ ) сплавами 3 домішками $\mathrm{Si}$ та $\mathrm{V}$ сягає 30-65 HRC, а зносостійкість їх у 20 разів перевищує зносостійкість сталі такої самої твердості.

Але електролітичний метод відновлення має недоліки [13,14]:

- гальванічні покриття досить значно знижують міцність деталей від утомленості: втрати міцності сягають 45 \% від вихідного значення;

- товсті хромові покриття (незважаючи на високу адгезійну міцність), мають підвищену крихкість і схильні відшаровуватися при знакозмінних навантаженнях деталей;

- гальванічні покриття можуть відшаровуватися при великих швидкостях роботи деталей, навіть при невисоких напруженнях (P=0,5 МПа);

- перед нанесенням гальванічних покриттів обов'язкова попередня підготовка, а після - фінішна обробка поверхні;

- забруднення води та велика ії витрата;

- висока потреба у електроенергії: перевищує витрати при електроіскровому нарощуванні (легуванні) понад 120-150 разів.

\section{Методи газотермічного напилення при відновленні зночених деталей машин}

Одним із прогресивних методів відновлення зношених деталей машин із поверхневим зміцненням $\epsilon$ газотермічне напилення [11, 12].

Особливістю технологічних процесів газотермічного напилення є одночасний вплив на розплавлений метал високої температури газового струменя і кінетичної енергії швидкості цього струменя. При цьому температура оброблюваної поверхні деталі не перевищує $300{ }^{\circ} \mathrm{C}$. Це дає змогу зберегти вихідну внутрішню будову і властивості основного матеріалу деталі.

Усі види газотермічного напилення є високотехнологічними процесами завдяки таким загальним позитивним характеристикам процесів: відсутність термічної деформації і металургійних змін поверхонь відновлених деталей; широкий інтервал товщини покриття (від сотих часток міліметрів до кількох міліметрів) при високій продуктивності виробничого процесу. Однак мікротвердість газоплазмового покриття становить 3000-5000 МПа, це у 1,5-2 рази нижче від твердості покриттів, отриманих електроіскровим легуванням [15].

Порівняння позитивних і негативних характеристик видів газотермічного методу та їх технологічних особливостей приведені в табл. 1 [11, 12]. 


\section{TEХНІЧНI НАУКИ}

\section{1. Переваги і недоліки основних видів газотермічної обробки}

\begin{tabular}{|c|c|c|}
\hline Переваги & Недоліки & Джерело \\
\hline \multicolumn{3}{|c|}{ Плазмово-дугове напилення } \\
\hline $\begin{array}{l}\text { - можливість отримати покриття матері- } \\
\text { алів із суттєвою різницею температури } \\
\text { плавлення; } \\
\text { - можливість регулювати в широких ме- } \\
\text { жах властивості струменя плазми; } \\
\text { - можливість гнучкого регулювання ре- } \\
\text { жимів роботи плазмотрона. }\end{array}$ & $\begin{array}{l}\text { - невисокий коефіцієнт корисного викорис- } \\
\text { тання енергії струменя; } \\
\text { - невисока міцність зчеплення покриття } 3 \\
\text { основою (15-50 МПа); } \\
\text { - високий рівень шуму і світловипроміню- } \\
\text { вання; } \\
\text { - висока вартість обладнання }\end{array}$ & 11,12 \\
\hline \multicolumn{3}{|c|}{ Газополуменеве напилення } \\
\hline $\begin{array}{l}\text { - можливість отримання покриттів з ма- } \\
\text { теріалів, які плавляться без розкладання; } \\
\text { - відносно низький рівень світлового ви- } \\
\text { промінювання і шуму; } \\
\text { - невисока вартість і мобільність, прос- } \\
\text { тота обслуговування устаткування; } \\
\text { - можливість напилення без демонтажу } \\
\text { машини. }\end{array}$ & $\begin{array}{l}\text { - обмеження по температурі плавлення } \\
\left(3000^{\circ} \mathrm{C}\right) \text { матеріалів для напилювання; } \\
\text { - доволі низька міцність зчеплення покриттів } \\
\text { з основою; } \\
\text { - невисокий коефіцієнт (2-12\%) використан- } \\
\text { ня енергії струменя на нагрів порошкового } \\
\text { матеріалу }\end{array}$ & 15 \\
\hline \multicolumn{3}{|c|}{ Електродугове напилення (металізація) } \\
\hline $\begin{array}{l}\text { - висока продуктивність процесу; } \\
\text { - високий коефіцієнт (70-90\%) корисно- } \\
\text { го використання енергії дуги на нагрів; } \\
\text { - можливість отримання покриття з міц- } \\
\text { ністю (60-80МПа) зчеплення; } \\
\text { - порівняно низька вартість обладнання. }\end{array}$ & $\begin{array}{l}\text { - інтенсивна взаємодія часток металу з акти- } \\
\text { вною газовою фазою; } \\
\text { - можливість використання для напилення } \\
\text { тільки дроту; } \\
\text { - високий (110-130 ДБ) рівень шуму техно- } \\
\text { логічного процесу }\end{array}$ & 11,12 \\
\hline
\end{tabular}

Як видно, практично усі види газотермічної обробки мають крім безперечних переваг доволі суттєві недоліки, основні з яких: невисока міцність зчеплення покриття з основою, невисокий коефіцієнт використання енергії струменя на нагрів матеріалу, високий рівень шуму і світлового випромінювання; доволі висока вартість технологічного обладнання.

\section{Лазерне наплавлення при відновленні знощених поверхонь деталей}

Використання лазерного наплавлення дає змогу створювати на робочих поверхнях відновлених деталей структури, що мають оптимальні експлуатаційні властивості $[9,16]$.

Лазерне наплавлення має низку позитивних властивостей $[15,17]$ :

- можливість створення на поверхні деталі шару металу із заданими властивостями (висока твердість, корозійна стійкість) шляхом введення легуючих елементів;

- можливість створення заданої шорсткості поверхні;

- висока мобільність лазерного променя, який можна направити на важкодоступні ділянки виробу;

- незначне нагрівання поверхні деталі, що практично не утворюється зона термічного впливу;

- автоматизація процесу обробки.

Завдяки параметрам технологічного процесу лазерного наплавлення, а саме: високим температурам (близько $\left.1500{ }^{\circ} \mathrm{C}\right)$, високим швидкостям нагрівання й охолодження $\left(10^{3}-10^{40} \mathrm{C} / \mathrm{c}\right)$, дуже короткому часу релаксації металу (10-11 c), а також великим значенням питомого навантаження енергії утворюються значні температурні градієнти (теплові потоки), що призводить до утворення метастабільних структур [16].

Основними недоліками лазерного способу відновлення деталей $є$ [17]:

- значна складність установок для лазерної обробки, а також потреба у висококваліфікованих фахівцях;

- обладнання для лазерного відновлення значно дорожче від обладнання для електроіскрового легування (нарощування); 


\section{ТЕХНІЧНІ НАУКИ}

- має місце зниження товщини зміцненого шару при малих швидкостях лазерного променя внаслідок екрануючої дії плазми;

- здійснення технологічного процесу потребує постійного контролю параметрів режиму.

Незважаючи на вищенаведені недоліки, усі ці методи відновлення зношених деталей зі зміцненням поверхневого шару успішно застосовуються в галузі технічного сервісу.

\section{Використання концентрованих потоків енергї̈ для відновлення зношених деталей}

Широке застосування у практиці підприємств технічного сервісу для відновлення і зміцнення зношених поверхонь знайшли методи, що грунтуються на використанні концентрованих потоків енергії з високою (понад $100 \mathrm{BT} / \mathrm{Mм}^{2}$ ) питомою потужністю в зоні нагріву. Судячи з результатів аналізу характеристик методів відновлення зношених деталей машин, найбільшу концентрацію енергії в зоні нагріву має електроіскрова обробка $[18,19]$.

Електроіскрове нарощування (легування)

Одним із відомих методів поверхневої обробки деталей машин концентрованими потоками енергії $\epsilon$ електроіскрове легування (нарощування).

Суть процесу електроіскрового легування полягає в такому [21, 22]. При досить великому проміжку між кінцями вібруючого електрода (2) і поверхнею деталі (1) електричний ланцюг розмикається і в ньому накопичується енергія (рис. 1). При зменшенні міжелектродного проміжку напруженість електричного поля зростає і стає достатньою для утворення між деталлю і електродом іскрового електричного розряду. Через канал, який утворився, миттєво проходить вся енергія, яка накопичилась у системі. Потік електронів, що рухається 3 дуже високою швидкістю, вдаряється в поверхню анода (електрода). Це миттєво нагріває частину його поверхні до дуже високої температури. Під дією температури цей невеликий об'єм анода плавиться, закипає і вибухає. Під час вибуху частинки розплавленого металу анода викидаються і, досягаючи поверхні деталі (катода), осідають на ньому [25].

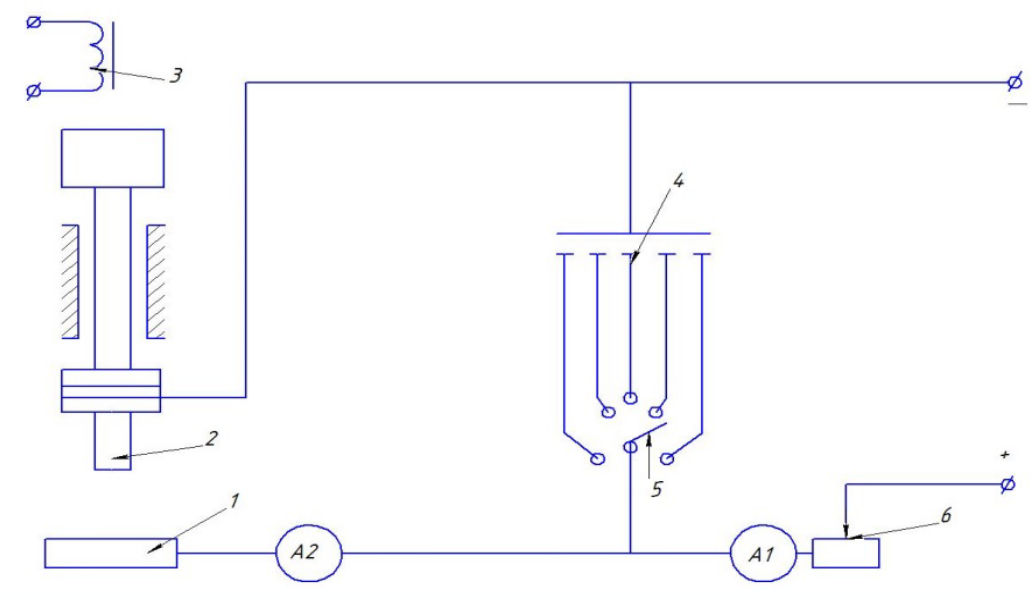

Рис. 1. Схема електроіскрової установки [27]:

1 - оброблювана деталь; 2 - електрод (анод); 3 - вібратор; 4 - конденсатор; 5 - перемикач; 6 -реостат; $A_{1}$ - амперметр мережі живлення; $A_{2}$ - амперметр розрядного ланцюга

Розглянемо коротко історію розвитку та галузі використання електроіскрової обробки металів.

Першими дослідниками електричних розрядів і ефектів, що їх супроводжують, були всесвітньо відомі вчені: Роберт Бойль (1694р.), Бенджамін Франклін (1751 р.), Джозеф Прістлі (1766 р.), Ліхтенберг Георг Крістіан (1777р.). 1938 року Л. О. Юткін показав, що серія електроіскрових розрядів створює формоутворюючі гідравлічні удари. Це започаткувало розвиток електроіскрового штампування металів [23].

У квітні 1943 року співробітники електротехнічного інституту, подружжя Борис та Наталія Лазаренки отримали авторське свідоцтво № 70010 на винахід «Способ обработки металлов и других токопроводящих материалов». Вони запропонували використати для формоутворення електроерозійні властивості розрядів у повітряному проміжку. Це і стало початком промислового використання електроіскрової обробки [24].

Після відкриття електріскрового методу обробки стало можливим не тільки здійснювати формоу- 
творення матеріалів незалежно від їх твердості, міцності та крихкості, а також змінювати структуру, фазовий, хімічний склад поверхні деталей з різних матеріалів.

Фундаментальні дослідження природи електричної ерозії металів стали основою теорії та методів розрахунку параметрів технологічних процесів. Стали реальністю нові можливості, а також розвязання завдання автоматизації технологічного процесу і створення гнучких технологічних процесів. Гррунтовні та детальні науково-дослідні роботи були проведені Н. І. Лазаренко, яка запропонувала фізичну модель процесу, дослідила масоперенос матеріалу анода на катод, механізм утворення покриттів, а також вплив на ці процеси енергетичних параметрів. На основі цих досліджень розроблені технології формування різних видів покриттів деталей машин, що можуть забезпечувати підвищення зносо-, жаро- і корозійної стійкості значної кількості деталей та інструменту [23].

3 моменту відкриття електроерозійного методу обробки металів декілька наукових шкіл інтенсивно i дуже успішно працювали над розвитком цього напряму. Наукові пошуки провадилися як у напрямі наукового поглиблення теорії процесів, так і в напрямі розробки технологій, що використовують імпульсні електричні розряди, зокрема, електроіскрове легування. Науковці Росії, України, Беларусі, Молдови, Чехії, Китаю та інших країн внесли свій вклад у розиток галузі. Зокрема, Б. Н. Золотих， А. Е. Гитлевич， В.В.Михайлов， Н.Я.Парканский, В.Н.Ткаченко, В. М. Ревуцкий, А. Д. Верхотуров, А. И. Михайлюк, П. А. Топала, А. П. Абрамчук, Т. В. Глабец, В. І. Іванов та багато інших талановитих науковців $[24,25]$. Було розроблено велику кількість технологічного обладнання для електроіскрової обробки металів. Деяки серії з них: «Разряд», «Плоскость», «Серебро», «Программа», «Антик», ЭФИ-87, «Элитрон» (рис. 2), зокрема, «Элитрон-354», «Элитрон-180», «ЭлитронТСП», «Элитрон-50 і 52» та інші. На рисунку 2 представлений зовнішній вигляд установки для електроіскрової обробки металів «Елітрон - 24А».

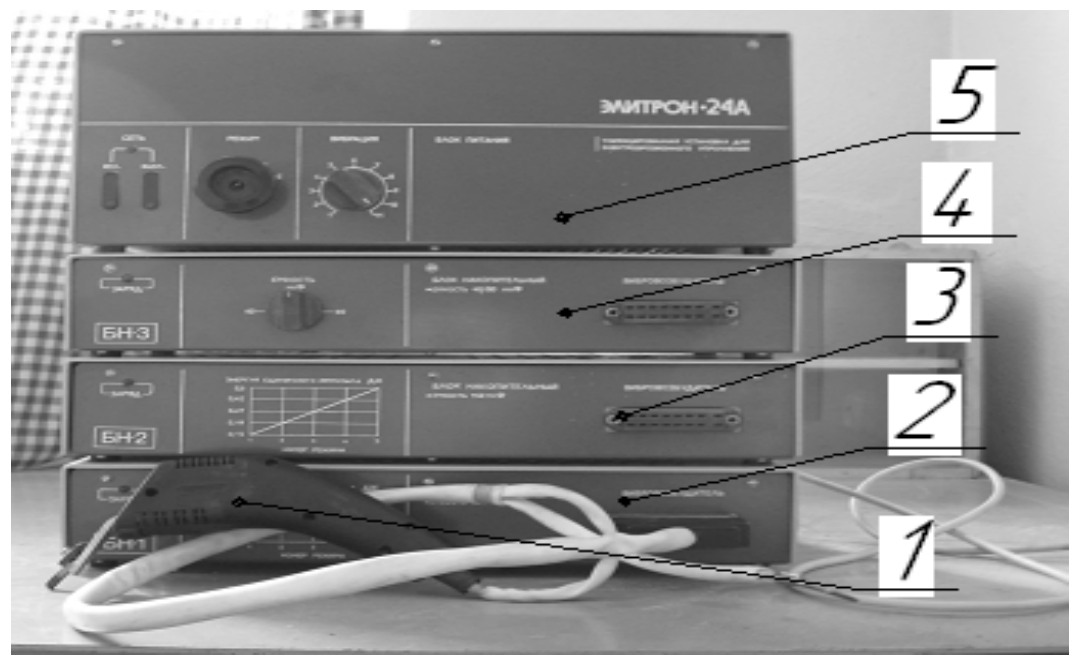

Рис. 2. Загальний вигляд установки «Елітрон - 24A» [29]:

1 - збудник вібраџії, 2-4 - накопичувальні блоки, 5 - блок живлення

Розроблена технологія електроіскрового легування порошковими матеріалами, використання якої дозволяє керувати структурою та властивостями сформованого шару. Це позитивно впливає на якість покриття. При формуванні покриття з $\mathrm{Cu}, \mathrm{Ni}, \mathrm{WC}+6 \%$ Co на поверхні деталі зі сталі 45 міцність зчеплення покриття у 2-2,5 раза вище, ніж при газополуменевому і плазмовому напиленні. Покриття $3 \mathrm{WC}$, Сr підвищують зносостійкість деталей порівняно з гартованою сталлю майже в 10 разів. Також доведено можливість створення ефективних жаро- і корозійностійких покриттів 3 алюмінію та його сплавів. Шляхом змін параметрів енергетичного режиму процеса, витратою порошка, можливе утворення як щільного покриття, так і покриття 3 капілярно-пористою структурою $[25,26]$. Практична цінність явища електроіскрової обробки полягає у тому, що попередня дія на поверхню деталі імпульсних розрядів дає змогу суттєво інтенсифікувати процеси дифузії. Якщо змінювати параметри імпульсів, то можливо змінювати глибину дифузії елементів на поверхні деталі.

Необхідно відмітити, що метод електроіскрового легування є одним з найбільш універсальних ме- 


\section{TEХНІЧНI НАУКИ}

тодів. Використання електроіскрового легування дає можливість моделювати практично усі методи покриттів з порошкових матеріалів: від газополуменевих до детонаційних. Прискорення і переміщення матеріалів здійснюється через газодинамічні та електродинамічні сили, тому не потребує транспортуючих газів. А їх нагрівання імпульсною плазмою забезпечує широкий діапазон температур частинок матеріалу - від плавлення до кипіння. Імпульсні плазмові потоки з частинками матеріалу дозволяють створювати шар покриття практично з будь-яких металевих та керамічних матеріалів.

Відновлення із застосуванням методів електроіскрової обробки нині використовують для: підвищення твердості та зносостійкості поверхні деталей машин, що працюють в умовах високих швидкостей обертання та великого навантаження, при підвищених температурах, в інертних газах; підвищення корозійної стійкості поверхні відновлених деталей; зміни властивостей інструментальних сталей та поверхонь виробів 3 кольорових металів [27, 28]. Застосування електроіскрового зміцнення робочих поверхонь валків прокатних станів гарячої прокатки, лопаток турбін, ножів землерийних машин, лопаток і крильчаток роторів, дробоструминних апаратів, корпусів роликових підшипників, підвищує їхню зносостійкість та корозійну стійкість удвічі-утричі. Як електроди (аноди) знаходять застосування легкоплавкі метали, полі-, монокристали металів, їх з’єднання з бором, вуглецем, азотом, а також стандартні тверді сплави.

Розроблена і використовується технологія відновлення плунжерних пар методом електроіскрового зміцнення. За допомогою електроіскрової обробки відновлюють деталі з чавуну, зокрема, вилки переключения передач коробки зміни швидкостей (коробка ZF). Успішно реалізуються технології відновлення блоку і головки циліндрів дизельного двигуна DXi 11 вантажного автомобілів «Вольво» 3 використанням установки «БІГ-4», як електроди застосовуються прутки з ніхрому Х20 Н80 діаметром 2 мм [25].

Електроіскрові покриття ефективно застосовуютья також при відновленні таких дефектів блоків циліндрів: знос корінних опор, знос гільз циліндрів [30, 32]. Технологія відновлення гільз передбачає після електроіскрового покриття операцію хонінгування на номінальний розмір.

Актуальність відновлення електроіскровим нарощуванням зростає для дизельних двигунів закордонної техніки, які конструктивно не мають змінних гільз, наприклад, у блоках Caterpillar (моделі 3116, 3126), у блоках MAH D 0836 (моделі LOH 55, 65) та інших, де гільза відлита суцільно 3 блоком. До нашої країни не поставляють ні ремонтні поршні, ні ремонтні поршневі кільця для цих моделей, що унеможливлює їхнє відновлення розточуванням на ремонтний розмір [25, 31$]$.

Отже, зважаючи на вищенаведене, можна зробити такий висновок. Ефективним методом поверхневого зміцнення при відновленні зношених деталей машин (виготовлених із конструкційних сталей) $\epsilon$ методи електроіскрової обробки, а саме, електроіскрового легування. Це дає змогу отримувати покриття, яке міцно зчеплене з матеріалом основи і має високі експлуатаційні характеристики.

Науковці виконали велику кількість грунтовних теоретичних та практичних розробок, які 3 успіхом використовуються у промисловості при виготовленні та при відновленні деталей машин різноманітного призначення: від ракето- і літакобудування до сільського господарства [32]. Значна кількість наукових досліджень присвячена вивченню структури та властивостей покриттів, отриманих у процесі електроіскрового легування.

Закономірності процесу електроіскрового легування залежать від матеріалу деталі та легуючого електрода, а також від режимів обробки, а саме: глибина і твердість зміцненого шару залежать від потужності режиму зміцнення. Зносостійкість і міцність від утомленості залежать від режимів технологічного процесу зміцнення і матеріалу електрода [26, 34].

Ефект зміцнення при електроіскровому легуванні забезпечується завдяки [30, 31]:

- утворенню твердих розчинів, хімічних з'єднань (оксидів, нітридів) у результаті взаємодії осадженого матеріалу з поверхнею деталі;

- подрібнюванню структури й утворенню нових фаз у результаті імпульсного впливу температури і тиску;

- високим фізико-механічним властивостям матеріалу анода.

Порівняно із вищезазначеними методами відновлення та поверхневого зміцнення деталей машин електроіскрове легування має такі переваги:

- висока міцність зчеплення матеріалу нанесеного шару з матеріалом деталі (основи) через механічне перемішування матеріалу і дифузійне проникнення легуючих матеріалів;

- деталь не нагрівається у процесі обробки, не відбуваються зміни фізико-механічних властиво- 


\section{TEХНІЧНI НАУКИ}

стей поверхні та ії геометричних параметрів;

- $є$ можливість застосування місцевого зміцнення окремих ділянок деталі (без розбирання агрегату);

- використовується малогабаритне і транспортабельне технологічне обладнання;

- електроіскрове легування відноситься до енергозберігаючих методів, оскільки енергоємність процесу у 100 разів нижча, ніж плазмового напилення (споживана потужність установок для електроіскрового легування $0,5-3,5$ кВт) [32];

- технологічний процес електроіскрового легування екологічно чистий;

- можлива фінішна обробка нанесених покриттів методами поверхнево-пластичного деформування [31];

- забезпечується можливість відновлення зношених деталей по мірі їхнього зносу змінної суцільності та товщини покриття;

- попередня підготовка оброблюваної поверхні до нанесення покриття не потрібна.

\section{Висновки}

У результаті виконаного нами порівняльного аналізу методів відновлення зношених деталей машин зі зміцненням поверхневого шару ми виявили, що електроіскровий метод (метод електроіскрового легування) може вважатися одним з оптимальних методів. Грунтуючись на результатах аналізу літературних джерел та досвіді підприємств технічного сервісу, виявили переваги та недоліки методу електроіскрового легування та 3'ясували можливості використання його для відновлення зношених поверхонь деталей сільськогосподарської техніки з метою підвищення надійності. Отже, можемо узагальнити результати.

Метод електроіскрового легування (нарощування) може бути альтернативним до традиційних технологій відновлення деталей $з$ поверхневим зміцненням. За деякими ознаками, зокрема низька енерноємність, малогабаритне і мобільне технологічне обладнання, процес $є$ екологічно чистим, він переважає більшість традиційних методів.

Тенденції розвитку технологій електроіскрового легування передбачають заміну дорогих тугоплавких компонентів електродних матеріалів новими, більш дешевими, але ефективними. Це робить його перспективним і досить привабливим для наукових досліджень та застосування у виробництві для відновлення зношених деталей машин.

Зважаючи на простоту використовуваного для електроіскрової обробки обладнання, цей метод відновлення може бути рекомендований для застосування в майстернях технічного сервісу.

Отже, ми виявили оптимальний метод для відновлення зношених деталей техніки, який формує зносостійку поверхневу структуру, має низьку температуру процесу, що виключає утворення зони термічного впливу.

Перспективи подальших досліджень. Зважаючи на вищенаведені дані, актуальною задачею є розробка технології відновлення конкретних зношених деталей сільськогосподарської техніки методом електроіскрового легування і вимагає проведення досліджень зі впливу електродних матеріалів та параметрів режиму процесу на властивості поверхонь відновлених деталей.

\section{References}

1. Dudnikov, A. A., Dudnik, V. V., Ivankova, O. V., \& Burlaka, O. A. (2019). Substantiation of parameters for the technological process of restoring machine parts by the method of plastic deformation. EasternEuropean journal of enterprise technologies, 1/1 (97), 75-80. doi: 10.15587/1729-4061.2019.156779

2. Afanas'yev, I. A., \& Kalhankov, Ye. V. (2016). Shlyakhy pidvyshchennya pislyaremontnoyi nadiynosti turbokompresoriv avtotraktornykh dvyhuniv. Zbior artykułow naukowych. Konferencji Miedzyn arodowej Naukowo Praktycznej [In Ukrainian].

3. Khanra, A. K., Pathak, L. C., \& Godkhindi, M. M. (2009). Application of new tool material for electrical discharge machining (EDM). Bulletin of Materials Science, 32(4), 401-405. doi: 10.1007/s12034-0090058-0

4. Rao, R. V., \& Pawar, P. J. (2009). Modelling and optimization of process parameters of wire electrical discharge machining. Proceedings of the Institution of Mechanical Engineers, Part B: Journal of Engineering Manufacture, 223 (11), 1431-1440. doi: 10.1243/09544054jem1559

5. Kalyon, A. (2020). Optimization of machining parameters in sinking electrical discharge machine of caldie plastic mold tool steel. Sädhanā, 45 (1). doi:10.1007/s12046-020-1305-8 


\section{TEХНIЧНI НАУКИ}

6. Ivankova, O. V. \& Bartosh, V. Yu. (2019). Doslidzhennya vplyvu zmitsnyuyuchykh tekhnolohiy vidnovlennya detaley na resurs mashyn. Visnyk Kharkivs'koho natsional'noho tekhnichnoho universytetu sil's'koho hospodarstva imeni Petra Vasylenka, 199, 54-61 [In Ukrainian].

7. Ho, K., \& Newman, S. (2003). State of the art electrical discharge machining (EDM). International Journal of Machine Tools and Manufacture, 43 (13), 1287-1300. doi: 10.1016/s0890-6955(03)00162-7

8. Prakash, V., Kumar, P., Singkh, P. K., Khuseyn, M., Das, A. K., \& Chattopadkh'yaya, S. (2019). Micro-electrical discharge machining of difficult-to-machine materials: A review. Journal of Engineering Manufacture, 233 (2), 339-370. doi: 10.1177\%2F0954405417718591

9. Lyashenko, B. A., Solovykh, Ye. K., \& Mirnenko, V. I. (2010). Optimizatsiya tekhnologii naneseniya pokrytiy po kriteriyam prochnosti i iznosostoykosti. Kiyev: IPP NAN Ukrainy [In Russian].

10. Skoblo, T. S., Goncharenko, A. A., Firsova, N. V., \& Legkobyt, A. N. (2019). Vosstanovleniye detaley elektrodugovoy naplavkoy s ispol'zovaniyem vtorichnogo syr'ya v usloviyakh sovremennykh agrarnykh klasterov. Materialy nauchno-prakticheskoy konferentsii studentov $i$ magistrantov BGATU [In Russian].

11. Student, M. M., Hvozdetskyi, V. M., Stupnytskyi, T. R., \& Dzioba, Y. V. (2017). Development of Electrometallic Equipment and Newest Consumables for Applying Protective and Reductive Coatings to Parts of Machinery Used in Mining, Transport, and Food Processing Industries. Science and Innovation, 13 (6), 34-38. doi: 10.15407/scine13.06.034

12. Gvozdecki, V. M. (2018). Electric arc restorative and protective coatings from cored wires. Visnik Nacional'noi' Academii' Nauk Ukrai'ni, 03, 79-84. doi: 10.15407/visn2018.03.079

13. Karakurkchi, A. V. (2015). Functional properties of multicomponent galvanic alloys of iron with molybdenum and tungsten. Functional Materials, 22 (2), 181-187. doi: 10.15407/fm22.02.181

14. Yar-Mukhamedova, G. S., Sakhnenko, N. D., Ved’, M. V., Yermolenko, I. Y., \& Zyubanova, S. I. (2017). Surface analysis of Fe-Co-Mo electrolytic coatings. IOP Conference Series: Materials Science and Engineering, 213, 012019. doi: 10.1088/1757-899x/213/1/012019

15. Skoblo, T. S., Rybalko, N. N., Tykhonov, A. V., \& Martynenko, A. D. (2019). Analyz sposobov yz·hotovlenyya, uprochnenyya y vosstanovlenyya lap kul'tyvatora. Tekhnichnyy servis ahropromyslovoho, lisovoho ta Transportnoho Kompleksiv, 15, 60-85 [In Ukrainian].

16. Carcel, B., Sampedro, J., Ruescas, A., \& Toneu, X. (2011). Corrosion and wear resistance improvement of magnesium alloys by laser cladding with Al-Si. Physics Procedia, 12, 353-363. doi: 10.1016/j.phpro.2011.03.045

17. Guzanova, A., Džupon, M., Draganovská, D., Brezinová, J., Viňáš, J., Cmorej, D., Janoško, E., \& Maruschak, P. (2020). The corrosion and wear resistance of laser and mag weld deposits. Acta Metallurgica Slovaca, 26 (2), 37-41. doi: 10.36547/ams.26.2.557

18. Lapenko, T. H. \& Prasolov, Ye. Ya., (2011) Vidnovlennya detaley sil's'kohospodars'kykh mashyn. Visnyk Poltavs'koyi derzhavnoyi ahrarnoyi akademiyi, 2, 140-144 [In Ukrainian].

19. Kryshtopa, S. I., Petryna, D. Y., Bogatchuk, I. M., Prun’ko, I. B., \& Mel’nyk, V. M. (2017). Surface Hardening of $40 \mathrm{KH}$ Steel by Electric-Spark Alloying. Materials Science, 53 (3), 351-358. doi: 10.1007/s11003-017-0082-y

20. Singh, S., Maheshwari, S., \& Pandey, P. C. (2004). Some investigations into the electric discharge machining of hardened tool steel using different electrode materials. Journal of Materials Processing Technology, 149 (1-3), 272-277. doi: 10.1016/j.jmatprotec.2003.11.046

21. Sydorenko, S. I., Ivashchenko, Ye. V., Lobachova, H. H., \& Franchik, N. V. (2014). Wearproof of fealloys surface zones after electric-spark alloying and laser treatment in complex composition saturating environments. Problems of Friction and Wear, 03(64), 105-109. doi: 10.18372/0370-2197.3(64).8608

22. Skoblo, T. S., Martynenko, A. D., Khar'yakov, A. V., Tykhonov, A. V., \& Kylymnyk, A. N. (2004). Povyshenye kachestva pokrytyy nanesennykh élektroyskrovym metodom. Visnyk Kharkivs'koho natsional'noho tekhnichnoho universytetu sil's'koho hospodarstva im. P. Vasylenka. Tekhnichnyy servis APK, tekhnika ta tekhnolohiyi u sil's'kohospodars'komu mashynobuduvanni, 23, 191-198 [In Ukrainian].

23. Verkhoturov, A. D., Gitlevich, A. Ye., \& Mikhaylov, V. V. (2011). Boris Romanovich Lazarenko avtor vydayushchikhsya otkrytiy v tekhnike XX veka. Uchenyy i organizator nauki. (K 100-letiyu so dnya rozhdeniya). Elektronnaya obrabotka materialov, 47 (1), 116-147 [In Russian].

24. Senetskiy, L. (2003). Vospominaniya slovatskikh mashinostroiteley k 60-letiyu elektroerozionnykh tekhnologiy. Elektronnaya Obrabotka Materialov, 2, 86-94 [In Russian]. 


\section{TEХНIЧНI НАУКИ}

25. Burumkulov, F. Kh., Lezin, P. P., Senin, P. V., Ivanov, V. I., Velichko, S. A., \& Ionov, P. A. (2003). Elektroiskrovyye tekhnologii vosstanovleniya i uprochneniya detaley mashin i instrumentov (teoriya i prakti$k a)$. Saransk: Krasnyy Oktyabr' [In Russian].

26. Ivankova, O. V., Velit, I. A., Bartosh, V. Yu., \& Yakimenko, D. I. (2020). Study of the influence of electrode materials on the properties surface of parts during recovery by the method of electro spark. Journal Modern Scientific Researches,13, 34-41. doi: 10.30889/2523-4692.2020-13-01-027

27. Bohatchuk, I. M., \& Prun'ko, I. B. (2015). Restavratsiya poverkhon' shypiv khrestovyn kardannykh valiv avtomobiliv za dopomohoyu elektroiskrovoho naroshchuvannya. Visnyk Natsional'noho Tekhnichnoho Universytetu «KHPI»: Avtomobile- ta traktorobuduvannya, 8 (1117), 36-41 [In Ukrainian].

28. Smolina, I., Franchik, N., \& Lobachova, G. (2011). The influence condition of electro-spark alloying by $\mathrm{Al}$ and sequent laser treatment on surface layer of steel GradeB A284. Journal "Challenges of modern technology”, 2 (3), 25-28 [In Ukrainian].

29. Bohatchuk, I. M., \& Prun'ko, I. B. (2016). Restavratsiya robochykh poverkhon' shtovkhachiv klapaniv dvyhuniv elektroiskrovym lehuvannyam z zastosuvannyam midnykh elektrodiv. Problemy Trybolohiyi, 3, 69-72 [In Ukrainian].

30. Kryshtopa, S. I., Petryna, D. Yu., Bohatchuk, I. M., Prun'ko, I. B., \& Mel'nyk, V. M. (2017). Poverkhneve zmitsnennya stali 40KH elektroiskrovym lehuvannyam. Fizyko-Khimichna Mekhanika Materialiv, 53, (3), 56-62 [In Ukrainian].

31. Martynenko, A. D., Skoblo, T. S, Sidashenko, A. I., Naumenko, A. A., \& Khar'yakov, A. V. (2003). Obpabotka PPD povepkhnosti pokpytiy, nanesennykh metodom EIO. Fizicheskiye i komp'yutepnyye tekhnologii $v$ napodnom khozyaystve: tpudy 8 Mezhdunapodnoy nauchno-tekhnicheskoy konferentsii [In Ukrainian].

32. Prun'ko, I. B, Bohatchuk, Yu. I., \& Student, M. M. (2009). Struktura ta zalyshkove napruzhennya u poverkhnevomu shari stolytsi 45 pislya elektroiskrovoho vyhotovlennya elektrodiv iz splaviv T15K6 ta VK8. Mizhvuzivs'kyy Zbirnyk Naukovi Notatky, 26, 255-260 [In Ukrainian].

33. Sarzhanov, B. A. (2019). Novyy sposib pidvyshchennya yakosti pokryttiv pry vidnovlenni detaley metodom elektroeroziynoho lehuvannya. Mizhvuzivs'kyy Zbirnyk Naukovi Notatky, 68, 96-102 [In Ukrainian].

34. Bohdanov, A. A., Protsyv, V. V., Patsera, S. T., \& Derbaba, V. A. (2020). Alhorytm vybora élektroda pry élektroyskrovom lehyrovanyy detaley. Visnyk Kharkivs'koho Natsional'noho Avtomobil'no-Dorozhn'oho Universytetu, 88 (1), 113-118. doi: 10.30977/BUL.2219-5548.2020.88.1.113 [In Ukrainian].

Стаття надійшла до редакції 11.10 .2020 р.

Бібліографічний опис для цитування:

Іванкова О. В., Гаращук О. В., К Куценко В. І., ЩЩербина В. В., Чижевський Д. В., Бабич Я. В., Тіхонов М. О. Дослідження методів відновлення зношених деталей сільськогосподарської техніки. Вісник ПДАА. 2020. № 4. С. 283-292.

(C) Іванкова Олена Володимирівна, Гарашук Олена Василівна, Кученко Віра Іванівна, Щербина Владислав Вікторович, Чижевський Дмитро Володимирович, Бабич Ярослав Володимирович, Тіхонов Максим Олександрович, 2020 